\title{
The value of Gleason Score Upgrade in Predicting Biochemical Recurrence After Radical Prostatectomy
}

\author{
Radikal Prostatektomi Sonrası Biyokimyasal \\ Rekürrensi Öngörmede Gleason Skoru \\ Yükselmesinin Değeri
}

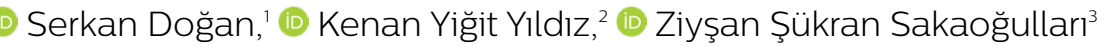

1Department of Urology, Sancaktepe Şehit Prof. Dr. Illhan Varank Training and Research Hospital, Istanbul

${ }^{2}$ Department of Urology

Kaçkar Government Hospital, Rize

${ }^{3}$ Department of Pathology Ankara State Hospital, Ankara

Cite this article as:

Doğan S, Yıldız KY Sakaoğulları ZŞ. The value of Gleason Score Upgrade in Predicting Biochemical Recurrence After Radical Prostatectomy. Bosphorus Med J 2021;8(2):88-92.

Received: 06.12.2020 Accepted: 27.01.2021

Correspondence: Dr. Kenan Yiğit Yıldız. Sancaktepe Şehit Prof. Dr. Illhan Varank Eğitim Ve Araştırma Hastanesi, Üroloji Kliniği, İstanbul, Turkey Phone: +905304681450

e-mail: kenanyigityildiz@gmail.com

\section{ABSTRACT}

Objectives: In this study, we aimed to investigate the effect of the Gleason score (GS) increase in the radical prostatectomy (RP) specimen compared to prostate biopsy material on predicting biochemical recurrence (BCR).

Methods: A total of 201 patients who underwent RP between 2012 and 2018 were included in the study. Patients were assigned to three groups: Upgrade, downgrade, and no change in GSs. These groups were compared in terms of positive surgical margins (PSMs) and BCR.

Results: There was no statistically significant difference between the groups according to age and pre-biopsy prostate-specific antigen. BCR rate was significantly higher in the upgrade group, while there was no significant difference in PSMs. The main limitation of our study was its short follow-up period.

Conclusion: Numerous studies have been conducted to predict biochemical relapse after RP. This study demonstrates that pathological upgrade may be useful as an independent predictor of recurrence.

Keywords: Biochemical recurrence; gleason upgrade; prostate adenocarcinoma.

\section{ÖZET}

Amaç: Bu çalışmada, prostat kanserli hastalardaki radikal prostatektomi spesmeninde; prostat biyopsi materyaline kıyasla gleason skorundaki artışın, biyokimyasal rekürrensi öngörmedeki etkisini araştırmak amaçlanmıştır.

Yöntem: 2012-2018 yılları arasında radikal prostatektomi prosedürü uygulanan toplam 201 hasta çalışmaya dahil edildi. Hastalar gleason skoru açısından; Artan, Azalan ve Değişmeyen olmak üzere 3 gruba ayrıldı. Bu gruplar pozitif cerrahi sınır ve biyokimyasal rekürrens açısından kıyaslandı.

Bulgular: Gruplar arasında yaş ve prostat biyopsi öncesi PSA değeri açısından anlamlı fark görülmedi. Artan grupta biyokimyasal rekürrens istatistiksel olarak anlamlı derecede daha fazla iken, pozitif cerrahi sınır açısından herhangi bir fark izlenmedi. Çalışmamızın ana sınırlayıcı etkeni kısa takip süresiydi.

Sonuç: Radikal prostatektomi sonrası biyokimyasal rekürrensi öngörmek adına birçok çalışma yapılmıştır. Bu çalışma radikal prostatektomi sonrası izlenen gleason skor artışının rekürrensi öngörmede bağımsız bir faktör olabileceğini göstermiştir.

Anahtar sözcükler: Biyokimyasal rekürrens; prostat adenokarsinomu; gleason skor artışı.

rostate adenocarcinoma $(\mathrm{PCa})$ is the most common malignancy in the USA and the second leading cause of cancer-related deaths in men. ${ }^{[1]}$
There are various therapeutic options for treating prostate cancer. ${ }^{[2]}$ Radical prostatectomy (RP) is accepted as the standard treatment for localized 
prostate cancer. ${ }^{[3]}$ However, some patients develop recurrence after surgery, which has been associated with a prostate-specific antigen (PSA), Gleason score (GS), and disease stage. ${ }^{[4]}$ Recurrence is also believed to originate from clinically undetectable micrometastatic traces of prostate cancer. ${ }^{[5]}$ Biochemical recurrence (BCR) is used as an early indicator of recurrent disease and/or metastasis. Following RP, BCR is defined by rising PSA values $>0.2 \mathrm{ng} / \mathrm{mL}$. ${ }^{[6]}$ Several studies have shown that BCR can reach up to $50 \%$ in long-term follow-up. ${ }^{[6,7]}$ Early detection or prediction of BCR is vital for clinical prognosis. Similarly, positive surgical margins (PSM) are also an independent risk factor for recurrent disease and/or metastasis. ${ }^{[8,9]}$ Many studies also indicate PSM as an independent risk factor of BCR. PSM is detected in up to $30 \%$ of cases after RP. ${ }^{[10]} \mathrm{PSM}$ does not always mean there will be a clinical disease, but it is a problem that must be well-managed.

Tumor differentiation evaluated with the Gleason grading system has been accepted as the most reliable indicator of prognosis and disease-related mortality in prostate cancer. GS upgrade occurs commonly in patients who underwent RP. Pre-operative low GS and small prostate volume have been associated with upgrade risk. This study investigated the value of GS upgrades in predicting BCR and PSM.

\section{Methods}

This study has been planned as a retrospective analysis. After the institutional review board and approval of Türkiye Yüksek İhtisas Training and Research Hospital Ethics Committee at January 2017 with research code 3715, a total of 201 patients with localized PCa revealed through transrectal ultrasound (TRUS) guided prostate biopsy and also underwent subsequent RP were included in our study (Table 1). Philips 260 Corvus Ultrasound (Amsterdam, Nederland) with 3.5-5 $\mathrm{MHz}$ TRUS probe was used for TRUS-Bx. Biopsy samples were obtained as 16 cores using 18-gauge needles with Pajunk DeltaCut Tru-Cut automated biopsy gun (Geisingen, Germany). While at least 12 cores are required for systematic

Table 1. Demographic characteristics of the patients

Patient number ( $\mathrm{n})$

Age (mean $\pm S D)$ (years)

Pre-operative PSA (mean \pm SD) $(\mathrm{ng} / \mathrm{ml})$

Prostate volume (mean; min-max) (cc)

Follow-up (mean $\pm S D)$ (months)

PSA: Prostate-specific antigen. prostate biopsy, we apply standard 16 cores in our clinic. All patients underwent retropubic RP.

Patients were assigned to three groups according to change in GSs of biopsy and surgical specimens: Upgrade, downgrade, and no change. According to the change in GS, Group 1 (no change) consisted of 107 patients, Group 2 (upgrade) 70 patients, and Group 3 (downgrade) 24 patients. In addition, the number of positive cores in the biopsy pathologies of patients and the clinical stage in the postoperative pathology were recorded. Patients were followed up for mean 42.4 \pm 13.4 months. Pathology results and age, pre-operative PSA, post-operative PSA, and the patients' PSMs were recorded. PSA $>0.2 \mathrm{ng} / \mathrm{dL}$ was considered a BCR. The groups were statistically compared according to BCR and PSM.

\section{Outcome Measurements and Statistical Analysis}

SPSS 22.0 package program (IBM, Armonk, NY/USA) was used for statistical analysis. Number, percentages, means, standard deviations, medians, and minimum and maximum values were used for descriptive statistics of the study. Since pre-operative PSA, post-operative PSA, and age were normally distributed, one-way analysis of variance was used to compare independent groups. A Chi-square test was used to compare PSM and BCR between the groups. $\mathrm{P}<0.05$ was considered statistically significant.

\section{Results}

According to the change in GS, Group 1 (no change) consisted of 107 patients, Group 2 (upgrade) 70 patients, and Group 3 (downgrade) 24 patients. The mean age of the groups was $67.4 \pm 6.6,66.6 \pm 7.5$, and $68.8 \pm 3.5$, respectively. Mean pre-operative PSA values were $10.02 \pm 8.84,10.14 \pm 6.16$, and $9.36 \pm 6.57$ $\mathrm{ng} / \mathrm{dL}$, respectively. Mean post-operative PSA values were $0.06 \pm 0.16,1.01 \pm 3.39$, and $0.02 \pm 0.05 \mathrm{ng} / \mathrm{dL} \mathrm{ng} / \mathrm{dL}$, respectively. There was no statistically significant difference between the groups according to age and pre-operative PSA. Post-operative PSA was significantly higher in Group 2. Clinical-stage and the number of positive cores were also found to be significantly higher in Group 2 . There was no difference between the groups in terms of prostate volumes and follow-up times (Table 2).

According to PSM, when groups were compared among themselves, there was a statistically significant difference according to BCR, but no statistically significant difference. BCR was found in 14 patients in Group 1, 19 patients in Group 2, and two patients in Group 3 (Table 2). 
Table 2. Clinicopathological characteristics of the study groups

\begin{tabular}{|c|c|c|c|c|}
\hline & Group 1 & Group 2 & Group 3 & $\mathbf{P}$ \\
\hline Patient number (n) & 107 & 70 & 24 & \\
\hline Age (mean $\pm S D)$ (years) & $67.4 \pm 6.6$ & $66.6 \pm 7.5$ & $68.8 \pm 3.5$ & 0.369 \\
\hline Pre-operative PSA (mean $\pm S D)(\mathrm{ng} / \mathrm{ml})$ & $10.02 \pm 8.84$ & $10.14 \pm 6.16$ & $9.36 \pm 6.57$ & 0.905 \\
\hline Post-operative PSA (mean $\pm S D)$ (ng/ml) & $0.06 \pm 0.16$ & $1.01 \pm 3.39$ & $0.02 \pm 0.05$ & 0.006 \\
\hline Prostate volume (mean $\pm S D)(c c)$ & $50.7 \pm 23.7$ & $53.5 \pm 17.9$ & $52.7 \pm 21.4$ & 0.751 \\
\hline Follow up time (mean $\pm S D$ ) (months) & $40.8 \pm 11.7$ & $43.6 \pm 14.1$ & $42.6 \pm 13.5$ & 0.813 \\
\hline Clinic stage, n (\%) & & & & 0.002 \\
\hline $\mathrm{T} 2$ & $73(68.2)$ & $26(37.1)$ & $16(66.7)$ & \\
\hline T3 & $34(31.8)$ & $44(62.9)$ & $8(33.3)$ & \\
\hline Positive core (mean) (min-max) & $2.8(2-9)$ & $4.1(2-14)$ & $2.6(2-7)$ & 0.013 \\
\hline $\operatorname{BCR}(n)$ & 14 & 19 & 2 & 0.027 \\
\hline $\operatorname{PCM}(n)$ & 24 & 19 & 6 & 0.512 \\
\hline
\end{tabular}

Group 1: Patients with no change in GS; Group 2: Patients with upgrade in GS; Group 3: Patients with downgrade in GS; BCR: Biochemical recurrence; PSM: Positive surgical margins; PSA: Prostate-specific antigen; GS: Gleason score.

\section{Discussion}

$\mathrm{PCa}$ is the most common malignancy, according to recent studies in man. ${ }^{[11]}$ PSA's introduction in clinical use has increased rates of early diagnosis, advancing surgical techniques, reduced complications, and survival rates with developing follow-up protocols. ${ }^{[12]}$ The Gleason grading system, first described in the mid-1960s, is still used as the most valuable predictor of prognosis and disease-specific survival. In this system, based on the evaluation of tumor cell differentiation, the first grade consists of the most dominant pattern. The second grade the second most dominant pattern, in which GS is the sum of these two grades. ${ }^{[13]}$ Scores of six and lower indicate the best prognosis, while scores of 8-10 may be accepted as indicators of poor prognosis. Scores of $>7$ indicate an increased risk of recurrence and progression. ${ }^{[14]}$ The low correlation between GS after TRUS biopsy and post-RP could potentially lead to inadequate or overtreatment in men with prostate cancer. High GS is widely known as an indicator of post-operative BCR. ${ }^{[15,16]}$

$\mathrm{RP}$ is still the gold standard treatment for the organ-localized disease. ${ }^{[3]} \mathrm{BCR}$ is detected in $35-50 \%$ of cases in 10 -year postoperative follow-up. ${ }^{[7]} \mathrm{BCR}$ may be an early indicator of recurrent primary disease or metastasis. It should also be kept in mind that BCR may not necessarily be associated with clinical recurrence, progression, or disease-specific mortality but may result from indolent prostate cancer or post-operative benign tissue. Predicting BCR will still help reduce morbidity and mortality associated with the disease.
Numerous studies have been conducted on preoperative PSA level, histological grade, PSMs, and clinical-stage to predict disease-related death. ${ }^{[17]}$

This study investigated whether or not patients with upgraded GS had an increased risk for BCR. According to biopsy results, the number of patients with GS $>7$ was 18 , which increased to 41 following pathological assessment of surgical specimens (Table 3). General literature also indicates that surgical pathology yields relatively higher scores than biopsy pathology. In the study, pre-operative PSA elevation, the number of positive cores, and clinical stage were determined as risk factors for GS upgrade. There are few studies on the prognosis and survey of this upgrade patient group. $[18,19]$ There are also few studies that mention the direct effect of this upgrade scoring on BCR. In addition to our study, in these studies, positivity rate in biopsy, PSA density, obesity, and smoking in risk groups for GS upgrade were also investigated. ${ }^{[20]}$

\section{Table 3. Pre-and post-operative data of the patients}

\begin{tabular}{lcc} 
GS & Biopsy specimen $\mathbf{n}(\%)$ & RP specimen n (\%) \\
\hline Gleason 3+3 & $144(72.6)$ & $100(49.8)$ \\
Gleason 3+4 & $21(10.4)$ & $34(16.9)$ \\
Gleason 4+3 & $16(8)$ & $26(12.9)$ \\
Gleason 4+4 & $14(7)$ & $23(11.5)$ \\
Gleason 4+5 & $4(2)$ & $18(8.9)$ \\
\hline
\end{tabular}

RP. Radical prostatectomy; GS: Gleason score. 
Yoo et al. ${ }^{[21]}$ conducted a study on 1582 patients. They reported poorer pathological stage and PSM results in upgraded patients, while biochemical failure rates were significantly higher in both upgrade and downgrade groups than in the no-change group. Açlkgöz et al. ${ }^{[22]}$ conducted a study on 152 patients in 2015 and reported no significant difference between an upgrade, downgrade, and no-change groups according to BCR. Park et al. divided 1678 patients with GS of seven into four groups: Upgrade 3+4, no change $3+4$, upgrade $4+3$, and no change $4+3$. BCR prevalence was significantly higher in the $4+3$ groups. When evaluated among themselves, it was found more prevalent in the $4+3$ no change group compared to the $4+3$ upgrade group. ${ }^{[23]}$ In our study, the upgrade was also found to be a significant indicator for BCR.

Another known risk factor for progression and/or metastasis after RP is PSM. ${ }^{[10]} \mathrm{PSM}$ also poses an increased risk for BCR. ${ }^{[24]}$ Pfitzenmaier et al. ${ }^{[25]}$ found a significant correlation between advanced clinical stage and PSM and indicated BCR rate was significantly higher in patients with PSM. Boorjian et al. ${ }^{[26]}$ found that survival without BCR was lower in patients with PSM than those without PSM. Stamey et al. ${ }^{[27]}$ concluded that PSM was not an indicator of BCR.

Poulakis et al. ${ }^{[28]}$ conducted a study using neural network analysis to evaluate comprehensive series and reported high GS and PSA were correlated with PSM. Yang et al. ${ }^{[29]}$ conducted a study on 296 patients to determine PSM indicators and significant correlation with GS. Itami et al. ${ }^{[30]}$ conducted a similar study on 381 patients and found a significant correlation between PSM and GS>7. The literature does not clearly define the effect of upgraded GS on PSM. Our study concluded that upgrade development was an independent risk factor for PSM, regardless of the score. The main limitation of our study was its short follow-up period.

\section{Conclusion}

Upgraded GS according to RP specimen is frequently encountered in daily practice. While upgrading may be an independent risk factor for BCR, regardless of the score, this is not the case for PSMs. Further studies with larger samples are required to research this subject.

\section{Disclosures}

Ethics Committee Approval: Ankara Türkiye Yüksek İhtisas Hospital Ethics Committee january 2018 with number 3715.

Peer-review: Externally peer-reviewed.
Conflict of Interest: None declared.

Authorship Contributions: Concept - S.D., K.Y.Y.; Design - S.D., K.Y.Y.; Supervision - S.D.; Materials - S.D., Z.S.; Data collection \&/or processing - S.D., K.Y.Y.; Analysis and/or interpretation S.D., Z.S.; Literature search - S.D., K.Y.Y.; Writing - S.D., K.Y.Y.; Critical review - S.D.

\section{References}

1. Siegel RL, Miller KD, Jemal A. Cancer statistics, 2016. CA Cancer J Clin 2016;66:7-30.

2. Martin DN, Starks AM, Ambs S. Biological determinants of health disparities in prostate cancer. Curr Opin Oncol 2013;25:235-41.

3. Bott SR. Management of recurrent disease after radical prostatectomy. Prostate Cancer Prostatic Dis 2004;7:211-6.

4. Ishizaki F, Hara N, Koike H, Kawaguchi M, Tadokoro A, Takizawa I, et al. Prediction of pathological and oncological outcomes based on extended prostate biopsy results in patients with prostate cancer receiving radical prostatectomy: A single institution study. Diagn Pathol 2012;7:68.

5. Mejean A, Vona G, Nalpas B, Damotte D, Brousse N, Chretien Y, et al. Detection of circulating prostate derived cells in patients with prostate adenocarcinoma is an independent risk factor for tumor recurrence. J Urol 2000;163:2022-9.

6. Mottet N, Bellmunt J, Briers E, Bolla M, Cornford P, De Santis M, et al. EAU-ESTRO-SIOG guidelines on prostate cancer. Part 1: Screening, diagnosis, and local treatment with curative intent. 2016;71:618-29.

7. Freedland SJ, Humphreys EB, Mangold LA, Eisenberger M, Dorey FJ, Walsh PC, et al. Risk of prostate cancer-specific mortality following biochemical recurrence after radical prostatectomy. JAMA 2005;294:433-9.

8. Boorjian SA, Thompson RH, Tollefson MK, Rangel LJ, Bergstralh EJ, Blute ML, et al. Long-term risk of clinical progression after biochemical recurrence following radical prostatectomy: The impact of time from surgery to recurrence. Eur Urol 2011;59:893-9.

9. Pound CR, Partin AW, Eisenberger MA, Chan DW, Pearson JD, Walsh PC. Natural history of progression after PSA elevation following radical prostatectomy. JAMA 1999;281:1591-7.

10. Obek C, Sadek S, Lai S, Civantos F, Rubinowicz D, Soloway MS. Positive surgical margins with radical retropubic prostatectomy: Anatomic site-specific pathologic analysis and impact on prognosis. Urology 1999;54:682-8.

11. Jemal A, Bray F, Center MM, Ferlay J, Ward E, Forman D. Global cancer statistics. CA Cancer J Clin 2011;61:69-90.

12. Semjonow A, Hamm M, Rathert P, Hertle L. Prostate-specific antigen corrected for prostate volume improves differentiation of benign prostatic hyperplasia and organ-confined prostatic cancer. Br J Urol 1994;73:538-43.

13. Gleason DF, Mellinger GT. Prediction of prognosis for prostatic adenocarcinoma by combined histological grading and clinical staging. J Urol 1974;111:58-64.

14. Epstein JI, Egevad L, Amin MB, Delahunt B, Srigley JR, Humphrey PA, et al. The 2014 International Society of Urological Pathology (ISUP) consensus conference on Gleason grading 
of prostatic carcinoma: Definition of grading patterns and proposal for a new grading system. Am J Surg Pathol 2016;40:24452.

15. Sim HG, Telesca D, Culp SH, Ellis WJ, Lange PH, True LD, et al. Tertiary Gleason pattern 5 in Gleason 7 prostate cancer predicts pathological stage and biochemical recurrence. J Urol 2008;179:1775-9.

16. Hattab EM, Koch MO, Eble JN, Lin H, Cheng L. Tertiary Gleason pattern 5 is a powerful predictor of biochemical relapse in patients with Gleason score 7 prostatic adenocarcinoma. J Urol 2006;175:1695-9; discussion 1699.

17. Roehl KA, Han M, Ramos CG, Antenor JA, Catalona WJ. Cancer progression and survival rates following anatomical radical retropubic prostatectomy in 3,478 consecutive patients: Longterm results. J Urol 2004;172:910-4.

18. Freedland SJ, Kane CJ, Amling CL, Aronson WJ, Terris MK, Presti JC Jr., et al. Upgrading and downgrading of prostate needle biopsy specimens: Risk factors and clinical implications. Urology 2007;69:495-9.

19. Kim KH, Lim SK, Shin TY, Lee JY, Chung BH, Rha KH, et al. Upgrading of Gleason score and prostate volume: A clinicopathological analysis. BJU Int 2013;111:1310-6.

20. Alchin DR, Murphy D, Lawrentschuk N. What are the predictive factors for Gleason score upgrade following RP? Urol Int 2016;96:1-4.

21. Yoo C, Oh CY, Cho JS, Song C, Seo SI, Ahn H, et al. Clinical significance of a large difference ( $\geq 2$ points) between biopsy and post-prostatectomy pathological Gleason scores in patients with prostate cancer. J Korean Med Sci 2011;26:507-12.

22. Açıkgöz O, Gazel E, Kasap Y, Yığman M, Güneş ZE, Ölçücüoğlu E. Factors effective on survival after radical prostatectomy: To what extent is pre-operative biopsy Gleason scoring is confident in predicting the prognosis? Urol Ann 2015;7:159-65.
23. Park J, Yoo S, Cho MC, Cho MH, Jeong CW, Ku JH, et al. The impact of pathologic upgrading of Gleason score 7 prostate cancer on the risk of the biochemical recurrence after radical prostatectomy. Biomed Res Int 2018;2018:4510149.

24. Ceylan C, Tonyali S, Keles I. Impact of positive surgical margin on biochemical recurrence following radical prostatectomy in locally advanced prostate cancer. Kaohsiung J Med Sci 2016;32:514-7.

25. Pfitzenmaier J, Pahernik S, Tremmel T, Haferkamp A, Buse S, Hohenfellner M. Positive surgical margins after radical prostatectomy: Do they have an impact on biochemical or clinical progression? BJU Int 2008;102:1413-8.

26. Boorjian SA, Tollefson MK, Rangel LJ, Bergstralh EJ, Karnes RJ. Clinicopathological predictors of systemic progression and prostate cancer mortality in patients with a positive surgical margin at radical prostatectomy. Prostate Cancer Prostatic Dis 2012;15:56-62.

27. Stamey TA, McNeal JE, Yemoto CM, Sigal BM, Johnstone IM. Biological determinants of cancer progression in men with prostate cancer. JAMA 1999;281:1395-400.

28. Poulakis V, Witzsch U, de Vries R, Emmerlich V, Meves M, Altmannsberger HM, et al. Preoperative neural network using combined magnetic resonance imaging variables, prostatespecific antigen, and Gleason score to predict positive surgical margins. Urology 2004;64:516-21.

29. Yang R, Cao K, Han T, Zhang YF, Zhang GT, Xu LF, et al. Perineural invasion status, Gleason score and number of positive cores in biopsy pathology are predictors of positive surgical margin following laparoscopic radical prostatectomy. Asian J Androl 2017;19:468-72.

30. Itami Y, Momose H, Ichikawa K, Mizobuchi S, Nakahama T, Matsumoto Y. Predictive factors of positive surgical margin in radical prostatectomy. Hinyokika Kiyo 2018;64:101-6. 